\title{
Natural Resource Enterprises: Payments to Landowners for Ecosystem Services from Forests and their Management in the United States of America (U.S.)
}

\author{
Walter Daryl JONES* \\ Department of Wildlife, Fisheries, and Aquaculture, Mississippi State University Extension Service
}

\begin{abstract}
Mississippi landowners were found to diversify incomes from forests through fee-access outdoor recreation, including hunting, angling, wildlife watching, and other nature-based activities (Jones et al. 2005). The Natural Resource Enterprises (NRE) Program at Mississippi State University educates private landowners, resource agencies, and local communities about recreational enterprises, conservation, and integration of these activities with sustainable forestry through educational workshops. Since 2005, the NRE Program has organized and conducted over 75 landowner workshops in 11 U.S. states and Sweden and trained in excess of 4,000 participants in outdoor recreational business development and associated conservation practices. Survey results revealed that our programming has initiated over 1,000 new outdoor recreational businesses on an estimated 1.2 million hectares of forest and agricultural lands, generating over \$14 million in incomes while fostering natural resource conservation on family farms in the U.S. NRE development on rural lands benefits landowners and local communities through promoting payments for ecosystem services supported by sustainable forests.
\end{abstract}

sustainability / forest management / landowners

Kivonat - Ökoturisztikai vállalkozások: Díjfizetés a földtulajdonosok számára az erd b l és az erd gazdálkodásból származó ökoszisztéma szolgáltatásokért az Amerikai Egyesült Államokban (USA). Mississippi földtulajdonosok díjfizet s természetközeli kikapcsolódási lehet ségekkel, például vadászattal, horgászattal, vadvilág megfigyeléssel és más természethez kapcsolódó szolgáltatásokkal diverzifikálták bevételeiket (Jones et al. 2005). A Mississippi Állami Egyetemen m köd Ökoturisztikai Vállalkozások Program (ÖVP) m helybeszélgetéseken keresztuil tart képzéseket földtulajdonosok, ügynökségek és a helyi közösségek képvisel i számára az ökoturisztikai vállalkozások, a természetvédelem és ezek erd gazdálkodással történ integrálása témakörében. 2005 óta az ÖVP $75 \mathrm{~m}$ helybeszélgetést szervezett meg és hajtott végre az USA 11 államában és Svédországban, és 4000-ret meghaladó résztvev t képzett az ökoturisztikai fejlesztés és a kapcsolódó természetvédelmi tevékenységek témakörében. Felmérési eredmények felfedték, hogy a program révén 1000 új ökoturisztikai vállalkozás indult el 1,2 millió hektárra becsült erd és mez gazdasági területen, 14 millió USD bevételt generálva, miközben a természeti er források védelmét is el segítette az USA családi agrárvállalkozásaiban. Az ÖVP fejlesztés a vidéki térségekben a tartamos erd gazdálkodás ökoszisztéma szolgáltatásaiért történ díjfizetések ösztönzésével a földtulajdonosok és a helyi közösségek számára is hasznot hajt.

\section{tartamosság / erd gazdálkodás / földtulajdonosok}

\footnotetext{
* daryl.jones@msstate.edu; Box 9690, Mississippi State University, MS 39762, USA
} 


\section{INTRODUCTION}

Ecosystem services can be defined as the direct and indirect contributions of ecosystems to human well-being (Economics of Ecosystems and Biodiversity 2010). These services support human survival and life qualities in a number of ways. Ecosystem services can be categorized in four primary types, including provisioning, regulating, habitat, and cultural services. Provisioning services are products from ecosystems, such as food, water, wood, fiber, genetic, and medicinal attributes. While regulating services are benefits to society from ecosystems including climate regulation, natural hazard regulation (i.e., coastal zone protection from hurricanes and typhoons resulting from coastal wetlands, water quality and quantity attributes from watersheds, waste management, and environmental benefits to agriculture (pest control and pollination)). Habitat services refer to wildlife and fisheries habitats within ecosystems that enhance biodiversity of species and genetic variability among individual species. Lastly, cultural services are societal benefits derived from healthy ecosystems, such as spiritual and religious enrichment, scholarly enrichment, outdoor recreation, and aesthetic values of the environment. Natural resource conservation, stewardship, and wise-use land management practices can provide these ecosystem services to society, particularly when commercial and private landowners are given economic incentives to manage lands in environmentally friendly ways.

Outdoor recreation, including recreational hunting, angling, wildlife watching, and ecotourism is one avenue that incentivizes natural resource conservation and sustainable landuse practices on private lands in the U.S. while providing ecosystems services benefitting society at large. Demand for quality outdoor recreation is popular throughout the world. U.S. citizens (87.5 million) spent over $\$ 145$ billion (U.S. dollars) on wildlife-related recreation in 2011 (U.S. Department of the Interior 2011). Past research found that revenues collected in 1998 from fee-access hunting on private lands in Mississippi ranged from \$2,964 to \$5,254 on average per landowner who offered access to property or $\$ 7.50-\$ 14.28 /$ ha, depending upon the region of the state evaluated. Net revenues averaged from $\$ 1,539$ to $\$ 3,244$ per landowner who provided hunting access or $\$ 3.95$ to $\$ 9.66 /$ ha (Jones et al. 2005). During 2005-2008, outdoor recreation increased Mississippi rural property values by $52 \%$ or $\$ 1,615 /$ ha and those tracts that were leased for recreational hunting averaged over \$61/ha (Brashier 2014). Property characteristics that statistically influenced sales prices of rural tracts were hectares comprised of diverse land covers dominated by forested and agricultural lands. Expenditures for outdoors recreation (hunting, angling, wildlife watching, horse trail riding, and other nature-based outdoor activities) were estimated at $\$ 2.7$ billion in economic returns to the State of Mississippi in 2008 (Henderson et al. 2010). Despite the economic and environmental benefits of fee-access outdoor recreation, only 10-14\% of Mississippi private landowners participated in these businesses on their properties, primarily due to concerns in accident liability and perceived incompatibility with traditional forestry and agricultural land uses (Jones et al. 2005). Similar trends in revenues and land values associated with fee-access wildlife and fisheries recreation have been documented in other southern U.S. states (Richardson et al. 1992, Richardson et al. 1996).

Marginal lands, such as agricultural field borders, wetlands and wetland forests, and forested riparian corridors along watersheds, are often difficult to farm or manage for timber production due to flooding problems or regulatory restrictions (National Research Council 1992). However, these properties are ideal for conserving wildlife and fisheries habitats and can be readily enrolled in fee-access recreational businesses and governmental cost-share assistance programs. Revenues from fee-access recreation on private lands were substantially greater on forested and managed agricultural lands, particularly bottomland hardwood forests and forested riparian buffers along watersheds. This finding reveals that private landowners 
can generate income from conservation and restoration of lands that were marginal for forestry, agriculture, or development (Jones et al. 2005, Jones et al. 2008). Additionally, these lands provided ecosystem services that benefit local and regional communities. This study also revealed that fee-access recreation and associated wildlife habitat conservation often times promoted by governmental cost-share assistance programs were compatible with agriculture and forestry, thereby providing incentives to landowners to diversify natural resource enterprises on their properties that encourage land and water conservation.

Natural resource enterprises may include diverse outdoor activities, wildlife-related recreation, and associated amenities such as hunting, angling, wildlife watching, agritainment or farm tours, horse trail riding, and rural bed and breakfast accommodations. Establishing these types of enterprises on family forests and farms provide multiple benefits and ecosystem services that include the diversification of income streams for rural families, land ownership retention, conservation and stewardship of the land, improved watershed integrity, high quality habitats for wildlife and fish, reduced regulatory measures for environmental protection (state and federal wetland regulatory protection programs), and sustainable rural development (Jones et al. 2005, Jones et al. 2008).

\section{NATURAL RESOURCE ENTERPRISES PROGRAM}

The Natural Resource Enterprises Program (NRE) (www.naturalresources.msstate.edu) was established in the Department of Wildlife, Fisheries, and Aquaculture and Cooperative Extension Service at Mississippi State University to educate rural landowners in the U.S. about fee-access recreational business development, wildlife and fish habitat management on farm and forest lands, and compatible land-use practices. Historically in the U.S., educational materials for natural resource enterprise development, though available, have been difficult to locate. As a result, landowners may not be aware of training opportunities and resources available. Working with program partners, we have developed educational workshops, demonstrations, and resources to inform landowners, agency professionals, and community leaders about enterprise opportunities, wildlife habitat management, and sustainable land uses on private lands. The NRE Program partners with federal resource agencies and state landgrant universities, farm bureaus and agricultural trade organizations, U.S. state agencies, nongovernmental organizations, and private-sector firms. Partners are actively trained in NRE and land management approaches and participate in workshops. Through these partnerships, we offer on-the-ground educational demonstrations and workshops to assist private landowners in outdoor recreational business development and conservation practices on their lands to enhance natural resources, including wildlife and fish and their associated habitats.

\section{WORKSHOP PROGRAMMING}

NRE workshops provide participants with the opportunity to learn from and interact with resource and agency professionals and existing operators of successful outdoor recreational businesses. We conduct workshops on properties that are currently in forestry or agricultural production and that also support a fee-access outdoor recreational enterprise.

During workshops, participants are given learning experiences including instructional lectures from resource professionals and field tours on properties with a fee-access recreational business. During lecture sessions, speakers from universities, resource agencies, and organizations discuss topics, such as revenue potential from outdoor recreational 
enterprises, business planning and management, legal considerations and liability reduction, governmental cost-share assistance, and habitat management considerations on the farm.

Attendees tour properties hosting events during afternoon sessions to observe enterprise operations and wildlife and fisheries habitats management integrated with forestry and farming practices. Each workshop attendee receives educational materials about enterprise operations, business management and marketing, liability reduction, wildlife and fisheries habitat management, cost-share assistance programs, and other topics pertinent to establishing and managing an enterprise.

\section{PARTICIPATION}

Workshops have been well received by past landowner, resource agency, and community leader participants. From 2005 to 2014, the NRE Program and partners have conducted over 70 landowner workshops and demonstrations in 11 U.S. states, including Alabama, Arkansas, Indiana, Louisiana, Michigan, Minnesota, Mississippi, Oregon, South Carolina, Tennessee, and Texas. Attendance at these events has been exceptional with over 4,500 participants, including an estimated 4,000 landowners with landholdings located in 16 U.S. states. The program participated in a conference and series of workshops sponsored by Lunds University (Dr. Marie Appelstrand) and the Swedish Forest Agency in 2009 to promote fee-access outdoor recreational enterprises within local communities in central Sweden.

To evaluate impacts from workshops, participants were mailed a comprehensive survey entitled Natural Resource Enterprises Landowner Survey that requested information about land-use practices, NRE businesses and conservation that have been implemented on farms since respondents attended a workshop, and additional information required to manage their properties. The Dillman method of survey design and administration was used in construction and mailing of the questionnaire to workshop participants (Dillman 1991). In June 2013 and 2014, questionnaires were mailed to past NRE workshop participants attending events from 2011 to 2014. Respondents to questionnaires were pooled with respondents from a survey mailing conducted in 2011 to participants of workshops from 2008-2010. The survey was divided between sections with questions related to landownership, cost-share assistance program participation, types of NRE's initiated on private lands and revenues collected from new business start-ups, informational needs on land management, and respondent demographics.

\section{RESULTS}

Survey response rate was 34\%, yielding an $\mathrm{N}$ size of 514 landowners (pooled from an estimated 30 workshops) who owned lands in 16 U.S. states. Respondents reported that they frequently utilized the NRE website (www.naturalresources.msstate.edu) to acquire information about wildlife management on their properties, business resources for establishing an NRE business, and to learn about upcoming training events. Other methods preferred by respondents for learning about NRE establishment in addition to attending workshops were watching videos (75\% viewed or were interested) and using a resource binder of educational materials provided to attendees at events (65\% of respondents). Resource materials sought by respondents were those about wildlife management (82\%), timber management $(80 \%)$, legal issues surrounding NRE operations (76\%), wildlife supplemental plantings (74\%), agritainment enterprises (63\%), fee hunting (62\%), and NRE business planning $(62 \%)$. 
Most workshop attendees were landowners $(91 \%)$ and had the following land uses on their properties: agriculture (78\%), forestry (63\%), personal recreation on property $(61 \%)$, feeaccess recreational businesses $(22 \%)$, and vegetable and mushroom production for sale $(18 \%)$. In terms of landownership, respondents $(\mathrm{n}=462)$ owned 220 hectares on average. Land covers on properties owned were primarily forested (mean $=148$ hectares/respondent), followed by agriculture (mean $=79$ hectares) and other lands such as fallow fields and wetlands (mean $=41$ hectares). Agricultural lands ranged from row crops (mean $=79$ hectares), pasture (mean $=26$ hectares), and aquaculture ponds (mean $=5$ hectares). Forested lands were dominated by planted pines and bottomland hardwood forests, 74 hectares and 59 hectares on average, respectively. Mixed pine hardwood forests averaged 44 hectares, followed by upland hardwoods (mean $=39$ hectares), natural pine (mean $=20$ hectares) and recently harvested cutover tracts averaged 14 hectares. Other lands owned by respondents consisted of wetlands and flooded fields (averaged 10 hectares), food plots for wildlife, roads, and rights of way (each cover type averaged 8 hectares), and fishing ponds (mean $=3$ hectares).

Conservation practices were implemented by respondents $(n=328)$ on an aggregate 5,856 hectares representing on average about 50 hectares per farm. Diverse practices were reported by respondents on their properties and included mowing $(56 \%)$, wildlife plantings (50\%), herbicide application (43\%), land disking (34\%), use of prescribed fire (30\%), and forest management (29\%). In terms of conservation practices information requested, respondents reported wildlife plantings, herbicide application, pond management, forest thinning, and prescribed burning were the subjects most sought. Over one-half of respondents reported that they had requested assistance from university extension staffs, agency biologists, or other land management experts to implement conservation and land management practices on their properties.

Nearly one-half of respondents reported that they had lands enrolled in U.S. Farm Bill conservation cost-share assistance programs. On average, these landowners collected $\$ 7,146$ (U.S. dollars) in annual contract payments, accounting for payments in excess of $\$ 1.25$ million. Conservation Reserve Program was the most popular cost-share assistance program participated in with 97 landowners reporting enrollments of 82 hectares on average per farm. Wetlands Reserve Program had 29 farmers participating who averaged 57 hectares enrolled on average, followed by Wildlife Habitat Incentives Program with 52 participants who averaged 19 hectares enrolled and Environmental Quality Incentives Program with 49 landowners who averaged 15 hectares enrolled per farm.

One hundred and sixty-four respondents (30\%) reported initiating an NRE business on their lands between 2011-2013 with 46 landowners establishing hunting leases, 40 feehunting operations, and 30 landowners starting fishing or agritainment operations. On average, landowners committed 329 hectares of their forests and farm lands to outdoor recreational businesses per farm, totaling over 54,000 hectares across all U.S. respondents. In terms of hunting species featured on lands, white-tailed deer $(n=101)$ and wild turkey $(n=62)$ were the most popular game species reported, followed by squirrel species, waterfowl, mourning dove, and rabbit. Landowners initiating NRE businesses collected on average $\$ 13,851$ per farm, totaling nearly $\$ 2.3$ million in aggregate cash flow from NRE's initiated (Table 1). Inferring these averages to the total number of landowners attending past workshops, an upper limit of new NRE business start-ups would equal 1,050 new NRE's established on an estimated 1.2 million hectares of forest and agricultural lands in the U.S., accounting for an aggregate cash flow of $\$ 14.5$ million U.S. dollars. Overall, respondents $(69 \%)$ reported that revenues met their income expectations. When asked reasons why landowners initiated these businesses, most reported income potential from NRE operations, land conservation management, recreational potential on their lands, improving wildlife and fish on their property, and for personal hobby and enjoyment. 
Lastly, most respondents did not have a business plan for their NRE and needed help in drafting such a document. To meet this need, we have initiated more advanced workshop formats to train landowners in drafting business plans to better guide their actions in starting new NRE ventures. Respondents reported that their business clients consisted of adult hunters, families, and out-of-town guests who learned about their outdoor excursions offered through word of mouth. When respondents were asked how they would prefer to learn about NRE business and land management opportunities in the future, most favored attending workshops. The majority of respondents were male (63\%), older than 56 years of age, over $90 \%$ Caucasian, college graduates, and slightly more than half lived on the property reported in the survey.

Table 1: Expected income of landowner respondents from natural resource enterprises developed on their properties in the U.S. from 2008-2013.

\begin{tabular}{ccc}
\hline $\begin{array}{c}\text { Expected income from } \\
\text { enterprise development }\end{array}$ & $\begin{array}{c}\text { Number of responses } \\
(\mathrm{N}=164)\end{array}$ & $\begin{array}{c}\text { Percentage }(\%) \text { of } \\
\text { total responses }\end{array}$ \\
\hline$\$ 0-\$ 1,000$ & 76 & 45 \\
$\$ 1,000-\$ 10,000$ & 47 & 29 \\
$\$ 10,001-\$ 25,000$ & 17 & 10 \\
$\$ 25,001-\$ 50,000$ & 13 & 8 \\
$\$ 50,001-\$ 75,000$ & 6 & 4 \\
$\$ 75,001-\$ 100,000$ & 1 & 1 \\
$\$ 125,001-\$ 150,000$ & 1 & 1 \\
Over $\$ 150,000$ & 3 & 2 \\
\hline
\end{tabular}

\section{CONCLUSION}

Past research has shown that private landowners earn additional revenues from their properties through fee-access outdoor recreational businesses. As a result, we have developed workshops to educate private landowners, state and federal resource agency staffs, and elected and nonelected community leaders about fee-access outdoors recreational enterprise development and integrated conservation practices on rural properties. Survey findings revealed that workshop participants have become more knowledgeable about and had implemented successful natural resource enterprises and associated land conservation management on rural properties located in U.S. states. Landowners earned income from these businesses and earnings met landowner expectations. Consequently, natural resource conservation practices conducted on private lands and associated with NRE development enhanced environmental protection on these working properties and thus, provided viable ecosystem services to rural communities in the U.S.

In terms of providing outreach programming in the U.S., multi-state stakeholder collaboration among land-grant universities, state and federal resource agencies, conservation and agricultural trade organizations, and private-sector groups has been vital to designing and implementing educational programming to attract and educate forest landowners and agricultural producers. Outreach programming promoting fee-access recreation and conservation on privately-owned U.S. lands can benefit landowners and local communities through sustainable economic development, environmental conservation, and land 
stewardship and retention. It is believed that this hands-on approach of participatory teaching, marketing, and information dissemination through workshop programming is effective at delivering quality land management training to landowners in rural America who oftentimes have difficulty in acquiring knowledge and skills. In this fashion, we can assist landowners in rural landscapes to diversify family incomes on their lands while enhancing land and water conservation, thereby strengthening local economies and providing ecosystem services and quality outdoor recreation on the U.S. land base that might not otherwise be provided if incentives were not present.

\section{REFERENCES}

Dillman, Don A. (1991): The Design and Administration of Mail Surveys. Annual Review of Sociology 17: 225-249

BRASHIER, J. The contribution of outdoor recreation on rural property sales in Mississippi. Retrieved from ProQuest Dissertation and Theses. (Accession Order No. [12007]).

Economics of Ecosystems and Biodiversity - TEEB. (2010): The Economics of Ecosystems and Biodiversity Ecological and Economic Foundations. Edited by Pushpam Kumar. Earthscan, London and Washington

Henderson, J. - GRADO, S. - MunN, I. - JONES, W. (2010): Economic impacts of wildlife- and fisheries-associated recreation on the Mississippi economy: an input-output analysis. Forest and Wildlife Research Center, Research Bulletin FO398, Mississippi State University. 21 p.

JONES, W. - JONES, J. - MUNN, I. - GRADO, S. (2005): Wildlife enterprises on Mississippi private lands. Proceedings of the $58^{\text {th }}$ Annual Conference of the Southeastern Association of Fish and Wildlife Agencies, 58: 344-355.

Jones, W. - Ring, J. - Jones, J. - WATSON, K. - PARVIN, D. - MunN, I. (2008): Land valuation increases from recreational opportunity: a study of Mississippi rural land sales. Proceedings of the Annual Conference of Southeastern Association of Fish and Wildlife Agencies. 60: 49-53.

NAtional Research Council (1992): Restoration of Aquatic Ecosystems. Commission on Geosciences, Environment, and Resources, National Academy Press, Washington, D.C. 552 p.

RichARDSON, C. - YARROW, G. - SMATHERS, W. (1992): Economic impact of hunting on rural communities in South Carolina. Clemson Univ. Coop. Ext. Serv. Publ. 26 p.

RichARDSON, C. - YARROW, G. - SMATHERS, W. (1996): Economic impacts of hunting on rural communities. Quality Whitetail. 3(2): 5-8.

U.S. Department of Interior, U.S. Fish and Wildlife Service and U.S. Department of Commerce, U.S. Census Bureau. (2011): National Survey of Fishing, Hunting, and Wildlife-Associated Recreation. Washington, D.C.: U.S. Government Printing Office. 
